\title{
A Study on Rent-seeking Behavior for Chinese Goverment Occupational Safety a nd Health Regulator Based on the Rent-seeking Theory
}

Dahan Yang ${ }^{12 \mathrm{a}}$; Shuyan Wei ${ }^{1 \mathrm{~b}}$

1.Northeastern University School of Humanlities and Low,110819,China;

2.Liaoning Research Institute of Industry and Inforamation Sciences,110021,China.

a.11619336@qq.com; b.wsy650@126.com

Key words: occupational safety and health regulation; rent-seeking; Rent-seeking behavior; Rent-seeking the ory.

Abstract: Rent-seeking is one of the inevitable topic in the process of government occupational saf ety and health(OSH) regulation, The behavior of regulator rent-seeking will let the regulatory failure s which may lead to a huge accident at last. According to the influence of rent-seeking theory, use “ will get the benefits" and "the possibility of being found" as the research variables, investigate the $S$ Y administration of work safety regulator which is in charge of the SY OSH with a questionnaire. Us e the data analysis to make clear that how the variables influence the goverment OSH regulation beh avior. Give the improvement suggestions for the goverment OSH regulation.

\section{Introduction}

Rent-seeking is the activity that people are engaged in for the pursuit of direct and unproductive prof its. As for civil servants, rent-seeking is the alienation of behaviors in the course of exercising publi c authority, which will give rise to the deficiency and target deviation of the established government al functions in the implementation process. In the course of OSH regulation, rent-seeking on the part of regulators will lead to the failure of regulation, which will threaten to people's life and properties as well as bring considerable additional costs to the regulated enterprises. What are the factors that af fect the behavior of the regulator? what circumstances lead the rent seeking behavior is more likely $t$ o occured? Is there a certain relationship between the rent seeking behavior of regulators and the bri be giver? The study will discuss the above in issues.

\section{Data Collection}

Questionnaire one: To investigate rent-seeking behavior in OSH regulation from the perspecti ve of regulator. The total number reaches 216. Through random sampling, this study chooses 50 peo ple for conducting the questionnaire survey, among which 48 are validated questionnaires.

Table 1: The summary sheet of the number of regulators accepting the interest-oriented rent-seekin g

\begin{tabular}{cccccc}
\hline & $\begin{array}{c}\text { must be f } \\
\text { ound }\end{array}$ & $\begin{array}{c}\text { probably b } \\
\text { e found }\end{array}$ & $\begin{array}{c}\text { sometiems b } \\
\text { e found }\end{array}$ & $\begin{array}{c}\text { Basically not b } \\
\text { e found }\end{array}$ & $\begin{array}{c}\text { cannot be f } \\
\text { ound }\end{array}$ \\
\hline a huge benefits & 2 & 2 & 11 & 19 & 11 \\
a great number of benefits & 0 & 1 & 5 & 14 & 24 \\
a lots of benefits & 0 & 0 & 3 & 13 & 28 \\
some benefits & 0 & 0 & 1 & 7 & 32 \\
a little benefits & 0 & 0 & 0 & 2 & 35 \\
\hline
\end{tabular}

Questionnaire two: To investigate the impacts of bribery on regulation from the perspective of the regulated. Observe object: the staff of the chemical plant, a fireworks manufacturing enterprise and a safety production management department of SY City. This survey involves 50 people through random sampling. The results are as follows:

Table 2: The number of the regulation objects who bribe under certain conditions

\begin{tabular}{cccccc}
\hline & $\begin{array}{c}\text { must be f } \\
\text { ound }\end{array}$ & $\begin{array}{c}\text { probably b } \\
\text { e found }\end{array}$ & $\begin{array}{c}\text { sometiems b } \\
\text { e found }\end{array}$ & $\begin{array}{c}\text { Basically not b } \\
\text { e found }\end{array}$ & $\begin{array}{c}\text { cannot be f } \\
\text { ound }\end{array}$ \\
\hline a huge benefits & 30 & 10 & 3 & 2 & 4 \\
a great number of benefits & 28 & 8 & 5 & 4 & 4 \\
a lots of benefits & 21 & 9 & 10 & 2 & 6 \\
some benefits & 18 & 4 & 8 & 5 & 8 \\
a little benefits & 15 & 1 & 9 & 7 & 13 \\
\hline
\end{tabular}

\section{Data Analysis}

This study carries out the chi square test to the data, and analyzes the differences between res 
ult and the theoretical value. The results are as follows:

Table 3: The chi-square test on the circumstances under which the regulators accept interest-orient ed rent-seeking

\begin{tabular}{cc}
\hline & number \\
\hline chi-square & $25.960^{\mathrm{a}}$ \\
$\mathrm{df}$ & 13 \\
Asymp.Sig. & .017 \\
Exact Sig. & .020 \\
Point probability & .005 \\
\hline
\end{tabular}

a.14 cells (100.0\%) have expected count less than 5 . The minimum expected count is 1.8

The precise significance level is $0.02<0.05$, which shows an obvious significance. Hence, the data collected through the questionnaire is typical, and the capture of the regulators is established un der certain fixed conditions, which means the possibilities of accepting the interest-oriented rent-see king on the part of regulators will be influenced by the two indexes mentioned above: the amount of obtained profits and the chances of detection.

Table 4:The chi-square test on the number of the regulation objects bribe under certain conditions

\begin{tabular}{lr}
\hline & number \\
\hline chi-square & $7.640^{\mathrm{a}}$ \\
df & 15 \\
Asymp.Sig. & .937 \\
Exact Sig. & .967 \\
Point probability & .041 \\
\hline
\end{tabular}

a. 16 cells (100.0\%) have expected count less than 5. The minimum expected count is 1.6

The precise significance level is $0.967>0.05$, which shows an unobvious significance. We will not investigate the distribution of the number of the regulation objects further.

To investigate into the impacts of the two indexes on the percentage of people accepting rent-se eking by exploring the correlation analysis on the data collected.

Table 5: The summary sheet of the layered percentage of conditions under which the regulators acc ept interest-oriented rent-seeking

\begin{tabular}{cccccc}
\hline & $\begin{array}{c}\text { must be f } \\
\text { ound }\end{array}$ & $\begin{array}{c}\text { probably b } \\
\text { e found }\end{array}$ & $\begin{array}{c}\text { sometiems b } \\
\text { e found }\end{array}$ & $\begin{array}{c}\text { Basically not b } \\
\text { e found }\end{array}$ & $\begin{array}{c}\text { cannot be f } \\
\text { ound }\end{array}$ \\
\hline a huge benefits & $4 \%$ & $8 \%$ & $30 \%$ & $68 \%$ & $90 \%$ \\
a great number of benefits & $0 \%$ & $2 \%$ & $12 \%$ & $40 \%$ & $88 \%$ \\
a lots of benefits & $0 \%$ & $0 \%$ & $6 \%$ & $32 \%$ & $88 \%$ \\
some benefits & $0 \%$ & $0 \%$ & $2 \%$ & $16 \%$ & $80 \%$ \\
a little benefits & $0 \%$ & $0 \%$ & $0 \%$ & $4 \%$ & $74 \%$ \\
\hline
\end{tabular}

When "the amount profits" is set as the control variable.

Table 6: The results of the partial correlation test between the chances of detection and the percenta ge of people accepting rent-seeking

\begin{tabular}{|c|c|c|c|c|}
\hline \multicolumn{3}{|c|}{ controlled variable } & \multicolumn{2}{|r|}{$\begin{array}{l}\text { the possibility of } \\
\text { being found }\end{array}$} \\
\hline \multirow[t]{6}{*}{ benefits } & percentage & interdependency & 1.000 & .851 \\
\hline & & Sig.(2-sided) & & .000 \\
\hline & & $\mathrm{df}$ & 0 & 22 \\
\hline & the possibility o & interdependency & 851 & 1.000 \\
\hline & $\mathrm{f}$ being found & Sig.(2-sided) & .000 & \\
\hline & & $\mathrm{df}$ & 22 & 0 \\
\hline
\end{tabular}


The obvious partial correlation between the chances of detection and the number of people is 0 . 851, and the significance level is 0.000 , which is representative. The chances of detection has an imp act on the possibilities of accepting rent-seeking on the part of regulators, and the higher the chances of detection are, the less likely the regulators choose rent-seeking behaviors, and vice versa.When “ the chances of detection" is set as the control variable, the results of the partial correlation test betwe en the amount of profits and the percentage are as follows:

Table 7: The results of the partial correlation test and the percentage of people

\begin{tabular}{lllrr}
\hline controlled variable & & & percentage & benefits \\
\hline the possibility of bei & percentage & interdependency & 1.000 & -.548 \\
& & Sig.(2-sided) &. & .006 \\
ng found & $\mathrm{df}$ & 0 & 22 \\
& \multirow{2}{*}{ benefits } & interdependency & -.548 & 1.000 \\
& & Sig.(2-sided) & .006 &. \\
& & $\mathrm{df}$ & 22 & 0 \\
\hline
\end{tabular}

When the chances of detection are set as the control variable, the relatively obvious partial corr elation between the amount of profits and the number of people is negative 0.548 , and the significan ce level is 0.006 , which is representative. The absolute value of the above two sets of data are $\mid 0.85$ $1|>|-0.548 \mid$ respectively,which means the "chances of detection" has a greater influence on the regulators than those of "the amount of profits".

We calculate and count the layered percentage of the regulated choosing to bribe under differe nt situations with different amount of profits and different chances of detection according to $t$ he survey results of the regulation objects. The results are as follows:

Table 8: The summary sheet of the layered percentage of the regulated choosing to bribe under cert ain conditions

\begin{tabular}{cccccc}
\hline & $\begin{array}{c}\text { must be f } \\
\text { ound }\end{array}$ & $\begin{array}{c}\text { probably b } \\
\text { e found }\end{array}$ & $\begin{array}{c}\text { sometiems b } \\
\text { e found }\end{array}$ & $\begin{array}{c}\text { Basically not b } \\
\text { e found }\end{array}$ & $\begin{array}{c}\text { cannot be f } \\
\text { ound }\end{array}$ \\
\hline a huge benefits & $60 \%$ & $80 \%$ & $86 \%$ & $90 \%$ & $98 \%$ \\
a great number of benefits & $56 \%$ & $72 \%$ & $82 \%$ & $90 \%$ & $98 \%$ \\
a lots of benefits & $42 \%$ & $60 \%$ & $80 \%$ & $84 \%$ & $96 \%$ \\
some benefits & $36 \%$ & $44 \%$ & $60 \%$ & $70 \%$ & $94 \%$ \\
a little benefits & $30 \%$ & $32 \%$ & $50 \%$ & $64 \%$ & $90 \%$ \\
\hline
\end{tabular}

Conducting partial correlation test to Table3 When "the amount profits" is set as the control vari able, the results of the partial correlation test between the chances of detection and the percentage of people accepting rent-seeking are as follows:

Table 9: The results of the partial correlation test and the percentage of people

\begin{tabular}{|c|c|c|c|c|}
\hline \multicolumn{3}{|c|}{ controlled variable } & \multirow{2}{*}{$\begin{array}{l}\text { the possibility o } \\
\text { f being found } \\
1.000\end{array}$} & \multirow{2}{*}{$\frac{\text { percentage }}{.949}$} \\
\hline benefits & the possibility of be & interdependency & & \\
\hline & ing found & Sig.(2-sided) & . & . 000 \\
\hline & & df & 0 & 22 \\
\hline & percentage & interdependency & .949 & 1.000 \\
\hline & & Sig.(2-sided) & .000 & . \\
\hline & & $\mathrm{df}$ & 22 & 0 \\
\hline
\end{tabular}

The obvious partial correlation between the chances of detection and the number of people is 0 . 949, and the significance level is 0.000 , which is representative. The chances of detection has an imp act on the possibilities of choosing to bribe on the part of the regulated, and the higher the chances 0 $\mathrm{f}$ detection are, the less likely the regulation objects choose to bribe, and vice versa. When "the chan ces of detection" is set as the control variable, the results of the partial correlation test between the a mount of profits and the percentage of people accepting rent-seeking are as follows:

Table 10: The results of the partial correlation test between the amounts of profits gained through $b$ ribery and the percentage of people accepting rent-seeking 


\begin{tabular}{lllrr}
\hline controlled variable & & & benefits & percentage \\
\hline the possibility of bei & benefits & interdependency & 1.000 & -.887 \\
ng found & & Sig.(2-sided) &. & .000 \\
& & df & 0 & 22 \\
& \multirow{2}{*}{ percentage } & interdependency & -.887 & 1.000 \\
& & Sig.(2-sided) & .000 &. \\
& & df & 22 & 0 \\
\hline
\end{tabular}

When the chances of detection are set as the control variable, the relatively obvious partial corr elation between the amount of profits and the number of people is negative 0.887 , and the significan ce level is 0.000 , which is representative. What's more, the control variable of "the chances of detect ion", which means the amount of profits gained through bribery has an impact on the possibilities of choosing to bribe, and the more lucrative the profits are, the higher the possibilities of choosing to br ibe, and vice versa. The absolute value of the above two sets of data are $|0.949|>|-0.887|$ respe ctively.

\section{Summary}

The amount of expected profits is one of the important factors that influences whether the regulators choose rent-seeking behaviors or not. Other things being equal, the more profits will be gained, the more likely the regulators choose rent-seeking behaviors, and vice versa.The chance of detection is one of the important factors that influences whether the regulators choose rent-seeking behaviors or not. Other things being equal, the higher the chances of detection are, the less likely the regulators c hoose rent-seeking behaviors, and vice versa.The amount of expected profits that the regulated will obtain through bribing is one of the important factors that influences whether the regulated choose $t$ o bribe or not. Other things being equal, the more profits will be obtained, the more likely the regula ted choose to bribe, and vice versa.The chance of detection is one of the important factors that influe nces whether the regulated choose to bribe or not. Other things being equal, the higher the chances o $\mathrm{f}$ detection are, the less likely the regulated choose to bribe, and vice versa.From the regulators' poi nt of view, the impacts of the chances of detection on rent-seeking behavior are greater than those of the amount of profits, which means the regulators are more concerned about the chances of detectio $\mathrm{n}$ as regard to the rent-seeking issue.From the point of view of the regulated, the impacts of the amo unt of profits on rent-seeking behavior are greater than those of chances of detection, which means $t$ he regulated are concerned more about the amount of profits as regard to the rent-seeking issue.

Foundation: Key project of Chinese National Social Science Fund. Number: 15AGL017.

\section{References}

[1] Lixinchun,Chenbin. The behavior and control failure of enterprise group failure: an analysis of t he system of product quality safety and supervision[J].Economic Research,2013.10.

[2] Luoshengqiang,Jiangyan. Research methods of management questionnaire[M]. Chongqing:Chon gqing University Press,2015.7.

[3] David marsh. Theory and method of Political Science[M].Beijing: China renmin University of Pr ess,2013.2. 